\section{pH Buffering in Pine Bark Substrates as a Function of Particle Size}

\author{
Magdalena Pancerz \\ The Ohio State University, Ohio Agricultural Research and Development \\ Center, 1680 Madison Avenue, Wooster, OH 44691
}

James E. Altland

Application Technology Research Unit, U.S. Department of Agriculture Agricultural Research Service, Agricultural Engineering Building, 1680 Madison Avenue, Wooster, OH 44961

Additional index words. sphagnum peat, Pinus taeda, irrigation, alkalinity, nutrient availability

\begin{abstract}
Stability of substrate pH in container-grown crops is important for proper nutrient management. The objective of this research was to determine the $\mathrm{pH}$ buffering capacity of pine bark substrates as a function of particle size and compare those results to sphagnum peat. The weight equivalent of $100 \mathrm{~cm}^{3}$ for fine, medium, and coarse pine bark and sphagnum peat, either as a whole or partitioned into several particle size ranges, was placed in a $250-\mathrm{mL}$ glass jar and filled with $100 \mathrm{~mL}$ of an acid or base solution ranging from 0 to $50 \mathrm{meq} \cdot \mathrm{L}^{-1}$ in $10 \mathrm{meq} \cdot \mathrm{L}^{-1}$ increments. After 24 hours, $\mathrm{pH}$ was measured. An experiment was also conducted in the greenhouse. The weight equivalent of $500 \mathrm{~cm}^{3}$ of sphagnum peat, fine pine bark, or coarse pine bark was filled into $10-\mathrm{cm}$ plastic pots and irrigated with one of the following: tap water or $10 \mathrm{meq} \cdot \mathrm{L}^{-1}$ of $\mathrm{HCl}, \mathrm{NaOH}, \mathrm{H}_{2} \mathrm{SO}_{4}$, or $\mathrm{KHCO}^{3}$ and with or without a water soluble fertilizer. Substrate pH was determined 4 and 8 weeks after potting using the pour-through method. In all experiments, sphagnum peat had less buffering capacity than pine bark against $\mathrm{pH}$ changes from acidic solutions, whereas pine bark had less buffering capacity than sphagnum peat to $\mathrm{pH}$ changes from basic solutions. Substrate $\mathbf{p H}$ buffering in pine bark increased with decreasing particle size, whereas pH buffering in sphagnum peat was less responsive to particle size. These results will help growers and substrate manufacturers understand how substrate components contribute to $\mathrm{pH}$ management during crop production.
\end{abstract}

Stability of substrate $\mathrm{pH}$ is an important factor in managing nutrition of containergrown crops. Some nursery and greenhouse crops have specific $\mathrm{pH}$ requirements. Walden and Epelman (1988) reported increased Japanese boxwood (Buxus microphylla Siebold \& Zucc. var. japonica) root and shoot growth with increasing dolomitic lime (DL) rate and concomitant increase in $\mathrm{pH}$. The increase in growth was attributed to a decrease in the ammonium $\left(\mathrm{NH}_{4}{ }^{+}\right)$-to-nitrate $\left(\mathrm{NO}_{3}{ }^{-}\right)$ratio because higher $\mathrm{pH}$ substrates resulted in more rapid nitrification of $\mathrm{NH}_{4}^{+}$to $\mathrm{NO}_{3}{ }^{-}$. Argo and Fisher (2002) identified three groups of floriculture crops based on $\mathrm{pH}$ requirements: a petunia group that is prone

\footnotetext{
Received for publication 26 Feb. 2020. Accepted for publication 8 Sept. 2020.

Published online 14 October 2020

Trade or brand names used in this publication does not constitute a guarantee or warranty of the product by the U.S. Department of Agriculture and does not imply its approval to the exclusion of other products or vendors that also may be suitable.

M.P. is a Visiting Scholar.

J.E.A. is a Research Horticulturist.

J.E.A. is the corresponding author. E-mail: james. altland@usda.gov.

This is an open access article distributed under the CC BY-NC-ND license (https://creativecommons. org/licenses/by-nc-nd/4.0/).
}

to iron deficiency at high $\mathrm{pH}$, a general group recommended to be grown at $\mathrm{pH} 5.8$ to 6.2 , and a geranium group prone to iron or manganese toxicity at low $\mathrm{pH}$. Crop preference for $\mathrm{pH}$ specificity could be related to the crop's native environment. For example, Harvey et al. (2004) reported that 'Aureola' hakonechloa [Hakonechloa macra (Makino) Honda] grew best in a 3 pine bark: 2 sphagnum peat: 1 sand (by volume) substrate with no DL amendment ( $\mathrm{pH} 4.5)$. They speculated this favorable response was due to the plant's adaptation to the low $\mathrm{pH}$ soil found in the mesic, forested mountains of its native range in Hakone, Japan.

Substrate $\mathrm{pH}$ of nonamended pine bark is generally 4.1 to 5.1 (Altland and Jeong, 2016) and is commonly increased using DL before potting. The two primary factors that increase or decrease $\mathrm{pH}$ after potting and during the production cycle are irrigation water alkalinity or ammoniacal fertilizers, respectively. Irrigation water alkalinity is a measure of carbonates, bicarbonates, and hydroxyl ions in solution. It increases substrate $\mathrm{pH}$ when these compounds, predominantly bicarbonate ions, react with the substrate solution to consume hydrogen ions and thus increase $\mathrm{pH}$ $\left(\mathrm{HCO}_{3}{ }^{-}+\mathrm{H}^{+}<=>\mathrm{H}_{2} \mathrm{CO}_{3}<=>\mathrm{CO}_{2}+\mathrm{H}_{2} \mathrm{O}\right)$. Irrigation water $\mathrm{pH}$ has relatively little effect on substrate $\mathrm{pH}$ compared with irrigation water alkalinity. Ramirez and Altland
(2018) reported that a $0.0001 \mathrm{~mm} \mathrm{KOH}$ solution with high $\mathrm{pH}$ (8.23) and low alkalinity $\left(10.0 \mathrm{mg} \cdot \mathrm{L}^{-1} \mathrm{CaCO}_{3}\right)$ did not increase substrate $\mathrm{pH}$ over 3 months, whereas a $0.005 \mathrm{M} \mathrm{KHCO}_{3}$ solution with similar $\mathrm{pH}$ (8.28) but high alkalinity (275 $\mathrm{mg} \cdot \mathrm{L}^{-1}$ $\mathrm{CaCO}_{3}$ ) increased substrate $\mathrm{pH}$ by more than 2 units after 3 months.

Many fertilizers acidify container substrates. Johnson et al., (2013) showed that fertilizer calcium carbonate equivalent (CCE) was effective in predicting the overall impact of a fertilizer on substrate $\mathrm{pH}$. Moreover, the authors (Johnson et al., 2013) noticed that a simple estimation of the acidity or basicity of a fertilizer could be determined by nitrogen form and concentration. Fertilizers containing urea $\left(\mathrm{CH}_{4} \mathrm{~N}_{2} \mathrm{O}-\mathrm{N}\right)$ or ammonium $\left(\mathrm{NH}_{4}{ }^{+}-\mathrm{N}\right)$ nitrogen decrease $\mathrm{pH}$ by nitrification of $\mathrm{NH}_{4}^{+}$to $\mathrm{NO}_{3}^{-}$, as well as $\mathrm{H}^{+}$release during root uptake of $\mathrm{NH}_{4}^{+}$to maintain charge balance (Lang and Elliott, 1991). Albano et al. (2017) showed that substrate pH of a 9 Florida peat: 9 pine bark: 2 sand substrate fertilized with a controlled release fertilizer (Osmocote 19N-2.6P-9.9K), containing $9 \% \mathrm{NH}_{4}{ }^{+}-\mathrm{N}$ and $10 \% \mathrm{NO}_{3}-\mathrm{N}$, decreased over time when irrigation alkalinity ranged from 50 to $150 \mathrm{mg} \cdot \mathrm{L}^{-1} \mathrm{CaCO}_{3}$.

The ability of a substrate to resist change in $\mathrm{pH}$ over time is termed $\mathrm{pH}$ buffering capacity. Buffering capacity can be affected by substrate components. Rippy et al. (2005) measured buffering capacity as the amount of base $\left(\mathrm{mol} \cdot \mathrm{kg}^{-1}\right)$ required to raise the $\mathrm{pH}$ of a peat sample from 5.4 to 6.2 and showed that buffering capacity varied among 64 sphagnum peat samples collected from bogs in Alberta, Canada. Despite the importance of substrate $\mathrm{pH}$ on crop growth in pine bark substrates (Altland and Jeong, 2016), there is no scientific literature on the ability of pine bark to buffer changes in $\mathrm{pH}$. Therefore, the objective of this research was to compare the $\mathrm{pH}$ buffering capacity of pine bark and its particle size fractions to nursery-grade sphagnum peat.

\section{Materials and Methods}

Three different commercial pine bark (Pinus taeda L.) substrates marketed as having different physical properties were obtained (Pacific Organics, Henderson, NC) and compared with sphagnum peat (Conrad Fafard Inc., Agawam, MA) for $\mathrm{pH}$ buffering capacity. The three pine bark substrates were subjectively labeled as being fine, medium, or coarse (Table 1), and all were screened on site and stored for less than 4 weeks. Pine bark samples were collected in May 2018 from the bark supplier during a site visit. From each bark pile, the top $10 \mathrm{~cm}$ was scraped away at three locations within the pile, and $\approx 30 \mathrm{~L}$ of pine bark was collected from each location, for a total volume of 90 L. Pine bark samples were transported back to Wooster, $\mathrm{OH}$, in $117-\mathrm{L}$ plastic containers and stored in a cooler at $4{ }^{\circ} \mathrm{C}$ until analyzed.

Substrate physical properties. Particle size distribution of each sample was determined 
using $\approx 100 \mathrm{~cm}^{3}$ of oven-dried substrate $\left(60{ }^{\circ} \mathrm{C}\right)$ and passing it through sieves sized 19.0, 12.5, 6.3, 4.0, 2.8, 2.0, 1.4, 1.0, 0.71, 0.50, $0.35,0.25,0.18$, and $0.11 \mathrm{~mm}$. Particles $\leq 0.11 \mathrm{~mm}$ were collected in a pan. Sieves and the pan were shaken for 3 min with a RX29/30 Ro-Tap sieve shaker (278 oscillations/ min, 150 taps/min; W.S. Tyler, Mentor, OH). Three replicate samples for each material were analyzed. Particle size distributions were subjected to multivariate analysis of variance (ANOVA) to determine whether distributions differed as a whole, then were analyzed by univariate ANOVA within each sieve size. Means were separated within a sieve size using Fisher's protected least significance difference test, where $\alpha=0.05$.

Pine bark and sphagnum peat samples were packed in $347-\mathrm{cm}^{3}$ aluminum cores (7.6 $\mathrm{cm}$ tall by $7.6 \mathrm{~cm}$ i.d.) according to methods described by Fonteno and Bilderback (1993). There were three replications for each substrate. Aluminum cores were attached to North Carolina State University Porometers (Horticultural Substrates Laboratory, North Carolina State University, Raleigh, NC), then saturated and drained for determination of air space (AS). Cores were weighed, oven dried for $4 \mathrm{~d}$ at $110^{\circ} \mathrm{C}$, and weighed again to determine container capacity (CC). Total porosity (TP) was calculated as the sum of AS and CC. Bulk density $\left(D_{b}\right)$ was determined using the oven dried $\left(110^{\circ} \mathrm{C}\right)$ substrate. Data were subjected to ANOVA to compare sphagnum peat and the three pine bark substrates.

pHbuffering of substrate type. The weight equivalent of $100 \mathrm{~cm}^{3}$ of each pine bark and sphagnum peat sample was determined by filling a graduated cylinder with each substrate individually and measuring the mass of $\approx 100 \mathrm{~cm}^{3}$. Three replications of each substrate type were then weighed, placed into $250-\mathrm{mL}$ glass jars, and $100 \mathrm{~mL}$ of an acid or base solution was added. Acid and base solutions were prepared with hydrochloric acid $(\mathrm{HCl})$ and sodium hydroxide $(\mathrm{NaOH})$, respectively, at concentrations ranging from 0 to $50 \mathrm{meq} \cdot \mathrm{L}^{-1}$ in $10 \mathrm{meq} \cdot \mathrm{L}^{-1}$ increments. Glass jars were sealed with lids and stirred for 10 min using a digital oscillator (Thermolyne Big Bill, Hogentogler \& Co. Inc., Columbia, $\mathrm{MD)}$ at 350 oscillations per minute. The stirring procedure was repeated after $24 \mathrm{~h}$ and $\mathrm{pH}$ (Mettler Toledo MA235 pH/Ion Analyzer, Columbus, $\mathrm{OH}$ ) was measured immediately after stirring. Resulting $\mathrm{pH}$ was fitted to a $\log$-logistic function $\mathrm{pH}=\mathrm{y}_{0}+\mathrm{a} /\{1+\exp$ $\left.\left[-\left(\mathrm{x}-\mathrm{x}_{0}\right) / \mathrm{b}\right]\right\}$, where $\mathrm{y}_{0}$ represents the lowest $\mathrm{pH}$ value of the substrate incurred by exposure to acidic solution, $\mathrm{y}_{0}+$ a represents the maximum $\mathrm{pH}$ value, $\mathrm{b}$ is a scaling factor such that the lower the value the more steep the slope transitioning from $\mathrm{y}_{0}$ to $\mathrm{y}_{0}+\mathrm{a}$, and $\mathrm{x}_{0}$ is the acid/base concentration (meq. $\mathrm{L}^{-1}$ ) at which the sigmoid curve changes from convex to concave (i.e., the inflection point). For purposes of curve fitting, meq. $\mathrm{L}^{-1}$ acid were expressed as negative values, and meq. $\mathrm{L}^{-1}$ base were expressed as positive values (Fig. 1). The experiment was repeated once. pH buffering by particle size fraction. Sphagnum peat and pine bark each were screened to three particle size fractions that represent the range of particles typically found in these substrates, including 0.18 to $0.25 \mathrm{~mm}, 0.71$ to $1.0 \mathrm{~mm}$, and 2.8 to $4.0 \mathrm{~mm}$. Next, two replications of each substrate and particle size fraction were mixed and $\mathrm{pH}$ was measured as previously described, except a weight equivalent to $20 \mathrm{~cm}^{3}$ was placed in a 50-mL conical tube (Falcon Plastics, Brookings, SD) and filled with $20 \mathrm{~mL}$ of an acid or base solution. A smaller volume of substrate was used for each sample due to the difficulty in screening the bark to very narrow particle size ranges. The experiment was repeated.

Greenhouse experiment. The fine and medium pine barks, along with the sphagnum peat evaluated in the first experiment, were evaluated for $\mathrm{pH}$ buffering capacity in a greenhouse validation study. Substrates were premixed with a dry media surfactant (AquaGro 2000M; Aquatrols Corp. of America,

Table 1. Percent particle size distribution of sphagnum peatmoss and three pine bark (Pinus taeda) products screened differently for various horticultural uses.

\begin{tabular}{|c|c|c|c|c|c|}
\hline \multirow[b]{2}{*}{ Sieve size $(\mathrm{mm})$} & Peatmoss & Fine bark & Med. bark & Coarse bark & $\overline{\operatorname{LSD}_{0.05}{ }^{z}}$ \\
\hline & \multicolumn{5}{|c|}{ 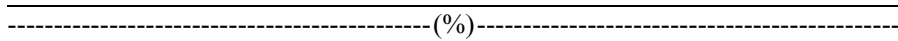 } \\
\hline Pan & 1.8 & 2.3 & 2.7 & 1.0 & 0.4 \\
\hline 0.11 & 4.5 & 4.1 & 3.3 & 1.3 & 0.3 \\
\hline 0.18 & 5.9 & 4.1 & 3.5 & 1.4 & 0.5 \\
\hline 0.25 & 8.6 & 7.0 & 4.9 & 2.5 & 0.8 \\
\hline 0.35 & 8.7 & 9.2 & 5.9 & 3.6 & 1.0 \\
\hline 0.50 & 10.9 & 13.7 & 8.3 & 6.1 & 1.4 \\
\hline 0.71 & 7.4 & 13.5 & 8.1 & 5.9 & 0.6 \\
\hline 1.00 & 6.4 & 15.9 & 9.1 & 7.0 & 1.1 \\
\hline 1.40 & 7.8 & 17.1 & 11.4 & 8.9 & 0.7 \\
\hline 2.00 & 7.3 & 9.3 & 11.5 & 9.5 & 0.8 \\
\hline 2.80 & 11.0 & 3.6 & 15.4 & 14.2 & 1.8 \\
\hline 4.00 & 12.2 & 0.3 & 12.6 & 19.9 & 2.9 \\
\hline 6.30 & 7.5 & 0.0 & 3.2 & 18.7 & 2.0 \\
\hline Fine $^{y}$ & 29.5 & 26.6 & 20.3 & 9.7 & 2.5 \\
\hline Medium & 39.8 & 69.5 & 48.5 & 37.5 & 3.1 \\
\hline Coarse & 30.7 & 3.9 & 31.2 & 52.8 & 5.3 \\
\hline
\end{tabular}

${ }^{\mathrm{z}}$ Fisher's least significant difference among values within the same row.

${ }^{\mathrm{y}}$ Fine particles are those in sieves $<0.50 \mathrm{~mm}$, medium particles are 0.50 to $2.00 \mathrm{~mm}$, and coarse particles are $>2.00 \mathrm{~mm}$.

Inc., Paulsboro, NJ) at 0.5 g. $\mathrm{L}^{-1}$ substrate. Ten-centimeter plastic pots $\left(\approx 600 \mathrm{~cm}^{3}\right.$ volume) were filled with a weight equivalent of $500 \mathrm{~cm}^{3}$ of each substrate and fully saturated with tap water. Six treatments solutions were applied three times per week with $100 \mathrm{~mL}$ solution added per pot each time. The six solutions consisted of tap water alone or tap water mixed with 10 meq. $\mathrm{L}^{-1} \mathrm{HCl}$ or $\mathrm{NaOH}$, or tap water mixed with $100 \mathrm{mg} \cdot \mathrm{L}^{-1} \mathrm{~N}$ from a water soluble fertilizer $(20 \mathrm{~N}-4.4 \mathrm{P}-16.6 \mathrm{~K}-$ $0.15 \mathrm{Mg}, 0.02 \mathrm{~B}-0.01 \mathrm{Cu}-0.1 \mathrm{Fe}, 0.05 \mathrm{Mn}-$ $0.01 \mathrm{Mo}-0.05 \mathrm{Zn}$ ) alone or additionally with $10 \mathrm{meq} \cdot \mathrm{L}^{-1}$ of sulfuric acid $\left(\mathrm{H}_{2} \mathrm{SO}_{4}\right)$ or potassium bicarbonate $\left(\mathrm{KHCO}_{3}\right)$. The watersoluble fertilizer was acidic, with a reported calcium carbonate equivalency of $200 \mathrm{~kg}$ per metric ton. Every substrate and solution combination consisted of eight single pot replicates. Substrate $\mathrm{pH}$ was determined initially for tap water control pots only and for all pots 4 and 8 weeks after potting using a modified pour-through method. Pots were watered three times with $200 \mathrm{~mL}$ tap water and left to drain for $30 \mathrm{~min}$. Each pot was then elevated over a saucer using a polyvinyl chloride ring. Subsequently, $40 \mathrm{~mL}$ of tap water was poured uniformly over the surface of each pot, avoiding the container edge. After $5 \mathrm{~min}$, leachate collected in the saucer was transferred into a $50-\mathrm{mL}$ conical tube. The tubes were capped and brought to the laboratory for $\mathrm{pH}$ measurement.

\section{Results and Discussion}

Substrate physical properties. Particle size distribution of the sphagnum peat and
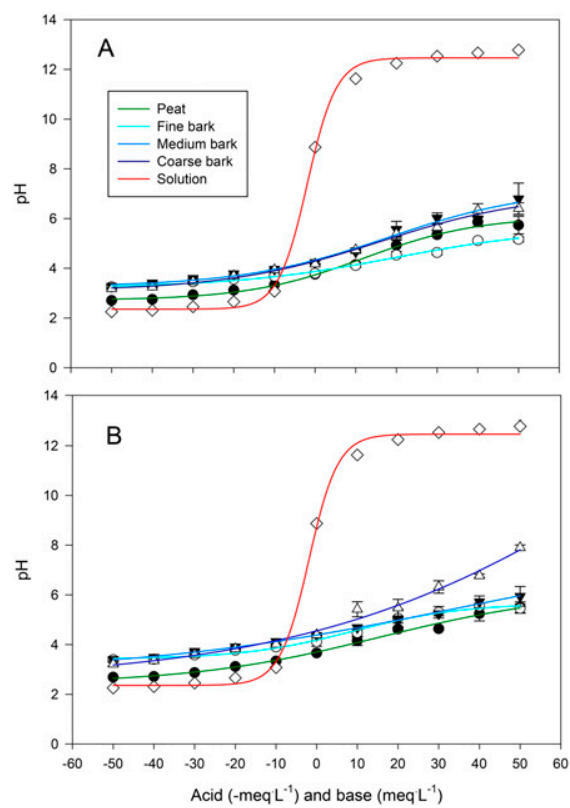

Fig. 1. Solution $\mathrm{pH}$ of peat and bark samples exposed to acid or base solutions from 0 to 50 meq. $\mathrm{L}^{-1}$. For graphing purposes, acid solutions are represented by decreasingly negative values in meq. $\mathrm{L}^{-1}$. The experiment was repeated, with panels $\mathbf{A}$ and $\mathbf{B}$ representing the first and second iterations, respectively. 
three pine bark substrates differed (Table 1). Sphagnum peat had a greater percentage of fine particles $(>0.5 \mathrm{~mm})$ than all pine bark textures, but a similar percentage of medium $(0.5$ to $2.0 \mathrm{~mm})$ and coarse particles $(>2.0 \mathrm{~mm})$ as the coarse- and mediumtextured pine barks, respectively. Among the three bark textures, the percent of fine and medium particles decreased whereas the percent of coarse particles increased as bark texture shifted from fine to coarse. Jackson et al. (2010) observed a similar phenomenon with pine tree substrates processed with a hammermill equipped with varying screen sizes. There were significant differences within each of the sieve sizes between the three bark textures; however, the largest differences occurred with the larger sieve sizes (Table 1). This is somewhat expected because these three bark textures were produced by a single company using varying combinations of screens to remove coarse particles.

The physical properties of the four substrates differed (Table 2). Peat and fine bark had similar AS, CC, and TP; however, $\mathrm{D}_{\mathrm{b}}$ of the fine or medium bark was more than twice that of the peat. Among the three bark textures, AS was greatest for the coarse bark, and $\mathrm{CC}$ decreased from fine to coarse textures. Because TP is calculated as the sum of $\mathrm{AS}$ and $\mathrm{CC}$, it tends to stay consistent across substrates with different particle sizes as the inverse relationship between AS and CC leads to relatively constant TP. Altland et al. (2018) previously showed that among pine bark sources with varying textures and wide-ranging $\mathrm{AS}$ and $\mathrm{CC}$, the inverse relationship between the two variables resulted in similar TP across bark sources.

pH buffering of substrate type. Sphagnum peat and the three pine bark textures had different $\mathrm{pH}$ buffering curves (Fig. 1). In the first iteration of the experiment, the $\mathrm{pH}$ of sphagnum peat and fine, medium, and coarse pine barks with pure water $\left(0 \mathrm{meq} \cdot \mathrm{L}^{-1}\right.$ acid or base) were $3.76,3.80,4.23$, and 4.17 , respectively (data not shown). Minimum solution $\mathrm{pH}$ was 2.36 . Sphagnum peat $\mathrm{pH}$ was reduced to 2.72 , but fine and medium bark $\mathrm{pH}$ was almost a half unit higher at 3.22 and 3.26, respectively, as depicted by the fitted parameter $\mathrm{y}_{0}$ representing the asymptotic minimum of the curve (Table 3). It appears that sphagnum peat had the least buffering capacity in acidic solutions as the $\mathrm{pH}$ of sphagnum peat was pulled closer to the solution $\mathrm{pH}$. The total reduction in $\mathrm{pH}$ of peat and fine, medium, and coarse bark in the most acidic solution was $1.06,0.55,0.96$, and $0.99 \mathrm{pH}$ units, respectively. From the standpoint of $\mathrm{pH}$ reduction in the strongest acid solution compared with that in pure water, fine bark was reduced the least while sphagnum peat and the medium and coarse bark were reduced by $\approx 1 \mathrm{pH}$ unit. However, because $\mathrm{pH}$ is a logarithmic value, the reduction of $\mathrm{pH}$ should be assessed on the change in acidity. The decrease in sphagnum peat $\mathrm{pH}$ from 3.76 to 2.72 required a greater change in acidity $\left(\Delta 0.0018 \mathrm{M} \mathrm{H}^{+}\right)$than a

Table 2. Physical properties of sphagnum peatmoss and several pine (Pinus taeda) bark products screened differently for various horticultural uses.

\begin{tabular}{|c|c|c|c|c|}
\hline \multirow[b]{2}{*}{ Substrate type } & Air space ${ }^{z}$ & Container capacity & Total porosity & \multirow[b]{2}{*}{ Bulk density $\left(\mathrm{g} \cdot \mathrm{cm}^{-3}\right)$} \\
\hline & \multicolumn{3}{|c|}{------------------------------ (\%) ----------------------------- } & \\
\hline Peat & 16.1 & 62.6 & 78.8 & 0.084 \\
\hline Fine bark & 17.1 & 62.4 & 79.5 & 0.176 \\
\hline Medium bark & 19.4 & 48.2 & 67.6 & 0.179 \\
\hline Coarse bark & 35.5 & 39.7 & 75.2 & 0.158 \\
\hline $\operatorname{LSD}_{0.05^{\mathrm{y}}}$ & 6.1 & 2.8 & 6.0 & 0.017 \\
\hline
\end{tabular}

${ }^{\mathrm{z}}$ Air space is percent volume of $7.6 \times 7.6-\mathrm{cm}$ core filled with air after saturation and drainage. Container capacity is percent volume of the same core filled with water after drainage. Total porosity is calculated as the sum of air space and container capacity.

${ }^{\mathrm{y}}$ Fisher's least significant difference among values within the same row.

Table 3. Estimated parameters for log-logistic curves that describe the buffering of pine bark against acidic and basic solutions ranging from $50 \mathrm{meq} \cdot \mathrm{L}^{-1}$ aciditiy to $50 \mathrm{meq} \cdot \mathrm{L}^{-1}$ basicity (Fig. 1).

\begin{tabular}{|c|c|c|c|c|c|}
\hline \multirow[b]{2}{*}{ Substrate } & $\mathrm{y}_{0}{ }^{\mathrm{z}}$ & $\mathrm{y}_{0}+\mathrm{a}$ & $\mathrm{b}$ & $\mathrm{x}_{0}$ & \multirow[b]{2}{*}{$r^{2}$} \\
\hline & \multicolumn{4}{|c|}{$\left(\mathrm{meq} \cdot \mathrm{L}^{-1}\right)$} & \\
\hline \multicolumn{6}{|l|}{ Expt. 1} \\
\hline Peat & 2.72 & 6.10 & 14.19 & 11.93 & 0.9969 \\
\hline Fine bark & 3.22 & 5.65 & 19.85 & 19.89 & 0.9950 \\
\hline Medium bark & 3.26 & 7.23 & 18.13 & 18.03 & 0.9917 \\
\hline Coarse bark & 3.09 & 7.04 & 19.02 & 15.83 & 0.9971 \\
\hline Solution & 2.36 & 12.47 & 3.59 & -1.90 & 0.9988 \\
\hline \multicolumn{6}{|l|}{ Expt. 2} \\
\hline Peat & 2.42 & 6.17 & 23.41 & 15.47 & 0.9959 \\
\hline Fine bark & 3.41 & 5.66 & 13.58 & 8.98 & 0.9950 \\
\hline Medium bark & 2.82 & 8.08 & 39.72 & 34.23 & 0.9990 \\
\hline Coarse bark & 2.49 & 19.99 & 42.15 & 84.95 & 0.9943 \\
\hline Solution & 2.24 & 12.34 & 3.59 & -1.90 & 0.9988 \\
\hline
\end{tabular}

${ }^{\mathrm{z}}$ Parameters estimated for the log-logistic function $\mathrm{pH}=\mathrm{y}_{0}+\mathrm{a} /\left\{1+\exp \left[-\left(\mathrm{x}-\mathrm{x}_{0}\right) / \mathrm{b}\right]\right\}$, where $\mathrm{y}_{0}$ represents the lowest $\mathrm{pH}$ value of the substrate incurred by exposure to acidic solution, $\mathrm{y}_{0}+$ a represents the maximum $\mathrm{pH}$ value, $\mathrm{b}$ is a scaling factor, and $\mathrm{x}_{0}$ is the acid/base concentration (meq. $\mathrm{L}^{-1}$ ) at which the curve changes from convex to concave. The parameter $r^{2}$ is the coefficient of determination for the model. similar reduction of $\mathrm{pH}$ in medium bark where $\mathrm{pH}$ was reduced from 4.23 to 3.28 $\left(\Delta 0.0004 \mathrm{M} \mathrm{H}^{+}\right)$. Therefore, peat had the least buffering capacity in acidic solutions. Poor acid $\mathrm{pH}$ buffering of sphagnum peat might in part explain the sudden $\mathrm{pH}$ decline observed with geranium (Pelargonium $\times$ hortorum L.H. Bailey) (Taylor et al., 2008), which are grown primarily in sphagnum peat-based substrates. Sphagnum peat had greater $\mathrm{pH}$ buffering against basic solutions than the medium or coarse bark in the first iteration of the experiment, although fine bark had the greatest buffering capacity against bases, with a maximum $\mathrm{pH}$ of 5.65 relative to the solution $\mathrm{pH}$ of 12.47 (Fig. 1). The change in molar $\mathrm{OH}^{-}$concentration followed the same trend as $\mathrm{pH}$. Fine bark increased the least $\left(4.42 \times 10^{-9} \mathrm{M} \mathrm{OH}^{-}\right)$, followed by sphagnum peat (increased $\left.1.24 \times 10^{-8} \mathrm{M} \mathrm{OH}^{-}\right)$, and the medium and coarse barks (increased 1.70 and $1.11 \times 10^{-7} \mathrm{M} \mathrm{OH}^{-}$, respectively). The fitted parameter $b$ of the log-logistic function could be indicative of $\mathrm{pH}$ buffering. The lower the value, the steeper the transition is from low $\mathrm{pH}$ values $\left(\mathrm{y}_{0}\right)$ to high $\mathrm{pH}$ values $\left(\mathrm{y}_{0}+\mathrm{a}\right)$. By extension, the steeper the transition, the fewer meq of acid or base are needed to change $\mathrm{pH}$, indicating lower $\mathrm{pH}$ buffering. Sphagnum peat had the lowest values for parameter $b$ in the first iteration of the experiment. In the second iteration of the experiment, sphagnum peat again exhibited lower acid $\mathrm{pH}$ buffering as well as greater base $\mathrm{pH}$ buffering than all pine bark textures (Fig. 1). The three pine bark textures had similar $\mathrm{pH}$ buffering when exposed to acidic solutions, whereas the coarse bark displayed lower $\mathrm{pH}$ buffering than the other two bark textures when exposed to basic solutions. The $\mathrm{y}_{0}+\mathrm{a}$ parameters for coarse bark in the second iteration of the experiment (Table 3) suggest maximum $\mathrm{pH}$ would be 19.99. This unreasonable value is likely due to how the data were fit with the log-logistic function to this particular data set. The $\mathrm{pH}$ response of this substrate (Fig. 1) over the range of acid and base solutions evaluated resembles a more quadratic polynomial response instead of a sigmoidal response.

pH buffering by particle size fraction. Sphagnum peat $\mathrm{pH}$ was $3.41,3.51$, and 3.38 for the $0.18-, 0.71-$, and $2.8-\mathrm{mm}$ particle size fractions, respectively, in pure water with 0 meq. $\mathrm{L}^{-1}$ acid or base (Fig. 2). Pine bark $\mathrm{pH}$ was $4.17,4.13$, and 4.11 for the same three particle size fractions, respectively, in pure water. Sphagnum peat $\mathrm{pH}$ decreased more $\left(\mathrm{y}_{0}\right)$ than pine bark when adding a strong acid solution to the fine particles $(0.18 \mathrm{~mm})$, but they both decreased a similar amount in the medium and coarse particles $(0.72$ and $2.8 \mathrm{~mm}$, respectively) (Table 4). However, sphagnum peat molar $\mathrm{H}^{+}$concentration was reduced greater than pine bark with each particle size class $[0.018$ vs. 0.001 $(0.18 \mathrm{~mm}), 0.016$ vs. $0.004(0.71 \mathrm{~mm})$, and 0.019 vs. $0.004(2.8 \mathrm{~mm}) \mathrm{M} \mathrm{H}^{+}$for peat vs. pine bark, respectively]. This corroborates the results observed in the first experiment. Elliott (1996) also showed that an acidic 

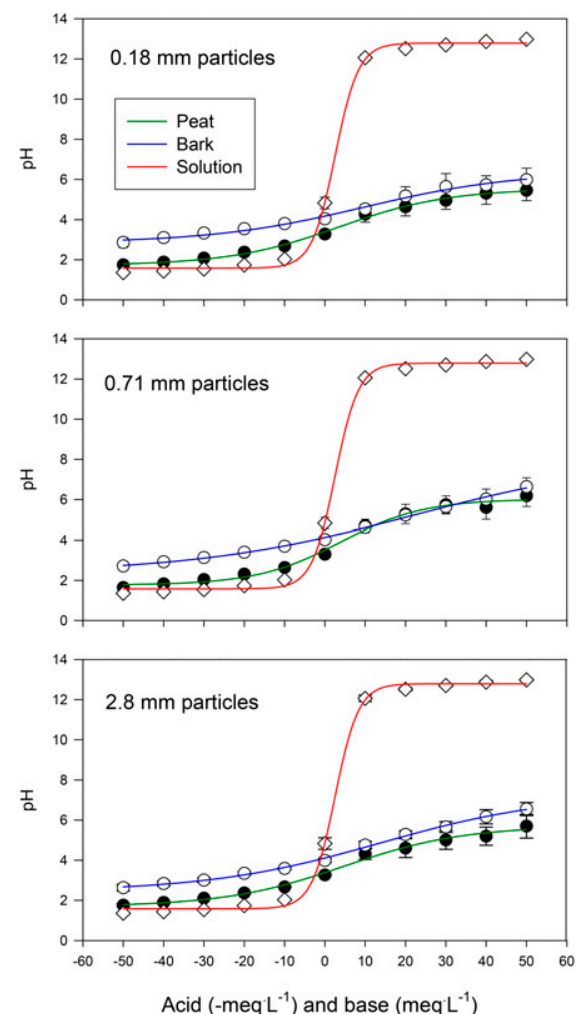

Fig. 2. Solution $\mathrm{pH}$ in pea or bark samples, sifted to $0.18-, 0.71-$, or $2.8-\mathrm{mm}$ particles and saturated in 0 to $50 \mathrm{meq} \cdot \mathrm{L}^{-1}$ of an acid or base solution. For graphing purposes, acid solutions are represented by decreasingly negative values in meq $\cdot \mathrm{L}^{-1}$.

fertilizer solution reduced $\mathrm{pH}$ in a sphagnum peat substrate ( 2 sphagnum peat: 1 vermiculite) greater than a bark substrate (2 sphagnum peat: 3 pine bark: 1 vermiculite). Both $\mathrm{pH}$ and molar $\mathrm{OH}^{-}$concentration in our study increased more in pine bark compared with sphagnum peat in all three particle size fractions, especially in the $0.71-\mathrm{mm}$ particle size, in which pine bark $\mathrm{pH}$ was more than 2 units higher and $\mathrm{M} \mathrm{OH}^{-}$concentration was more than two orders of magnitude greater than sphagnum peat. Jackson et al. (2010) likewise showed that sphagnum peat was more resistant to change in $\mathrm{pH}$ from limestone addition compared with pine tree substrates that included pine bark and wood. Similar to the first experiment, the $b$ parameter was lower for sphagnum peat in all three particle size fractions compared with pine bark, indicating a steeper transition between minimum and maximum $\mathrm{pH}$ and thus less buffering capacity at low to moderate $\left(<20\right.$ meq. $\left.\mathrm{L}^{-1}\right)$ acid and base additions.

Greenhouse experiment. Irrigation water treatments used in the experiment had wideranging $\mathrm{pH}$ and alkalinity to simulate how acidic and basic solutions affect substrate $\mathrm{pH}$ under typical irrigation practices (Table 5). At the initiation of the experiment, sphagnum peat, fine bark, and coarse bark had $\mathrm{pH}$ of $3.41,5.37$, and 4.81 , respectively (Table 6 ). The $\mathrm{pH}$ of all three substrates remained stable over the 8-week experimental period when

Table 4. Estimated parameters for log-logistic curves that describe the buffering of peatmoss or pine bark, each screened to one of three different particle sizes, against acidic and basic solutions ranging from 50 meq. $\mathrm{L}^{-1}$ acidity to $50 \mathrm{meq} \cdot \mathrm{L}^{-1}$ basicity (Fig. 2 ).

\begin{tabular}{|c|c|c|c|c|c|c|}
\hline \multirow[b]{2}{*}{ Particle size } & \multirow[b]{2}{*}{ Substrate } & $\mathrm{y}_{0}^{\mathrm{z}}$ & $\mathrm{y}_{0}+\mathrm{a}$ & $\mathrm{b}$ & $\mathrm{x}_{0}$ & \multirow[b]{2}{*}{$r^{2}$} \\
\hline & & \multicolumn{4}{|c|}{$\left(\mathrm{meq} \cdot \mathrm{L}^{-1}\right)$} & \\
\hline \multirow{2}{*}{$0.18 \mathrm{~mm}$} & Peat & 1.73 & 5.55 & 13.66 & 3.35 & 0.9982 \\
\hline & Bark & 2.84 & 6.40 & 18.99 & 9.66 & 0.9960 \\
\hline \multirow[t]{2}{*}{$0.71 \mathrm{~mm}$} & Peat & 1.77 & 6.02 & 10.44 & 3.85 & 0.9957 \\
\hline & Bark & 2.36 & 8.11 & 27.48 & 22.20 & 0.9987 \\
\hline \multirow[t]{3}{*}{$2.8 \mathrm{~mm}$} & Peat & 1.69 & 5.71 & 14.84 & 4.75 & 0.9960 \\
\hline & Bark & 2.44 & 7.30 & 21.56 & 13.84 & 0.9987 \\
\hline & Solution & 1.58 & 12.79 & 2.91 & 2.56 & 0.9995 \\
\hline
\end{tabular}

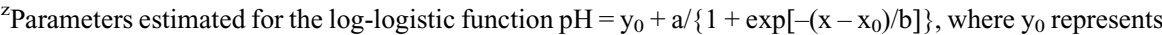
the lowest $\mathrm{pH}$ value of the substrate incurred by exposure to acidic solution, $\mathrm{y}_{0}+$ a represents the maximum $\mathrm{pH}$ value, $\mathrm{b}$ is a scaling factor, and $\mathrm{x}_{0}$ is the acid/base concentration (meq. $\mathrm{L}^{-1}$ ) at which the curve changes from convex to concave. The parameter $r^{2}$ is the coefficient of determination for the model.

Table 5. Treatment $\mathrm{pH}$ and alkalinity created by adding $\mathrm{HCl}$ or $\mathrm{NaOH}$ to tap water or an acidic water soluble fertilizer (Fert.), $\mathrm{H}_{2} \mathrm{SO}_{4}$, or $\mathrm{KHCO}_{3}$ to tap water.

\begin{tabular}{lccc}
\hline Acid/base & Fertilizer & $\mathrm{pH}$ & Alkalinity $\left(\mathrm{mg} \cdot \mathrm{L}^{-1} \mathrm{CaCO}\right)$ \\
\hline Tap water & - & $8.72 \pm 0.36$ & $47.8 \pm 4.5$ \\
$\quad$ control & - & $1.96 \pm 0.10$ & $0.0 \pm 0.0$ \\
$\mathrm{HCl}$ & - & $12.46 \pm 0.37$ & $375.0 \pm 80.1$ \\
$\mathrm{NaOH}$ & Fert. & $7.27 \pm 0.29$ & $48.6 \pm 6.0$ \\
$\mathrm{Tap}$ water & Fert. & $2.05 \pm 0.10$ & $0.0 \pm 0.0$ \\
$\mathrm{H}_{2} \mathrm{SO}_{4}$ & Fert. & $8.36 \pm 0.38$ & $519.4 \pm 54.2$ \\
$\mathrm{KHCO}_{3}$ & & \\
\hline
\end{tabular}

Table 6. Substrate $\mathrm{pH}$ in peatmoss, fine pine bark, and coarse pine bark after irrigation with tap water amended with either 10 meq. $\mathrm{L}^{-1}$ of $\mathrm{HCl}, \mathrm{NaOH}, \mathrm{H}_{2} \mathrm{SO}_{4}$, or $\mathrm{KHCO}_{3}$ and with or without 20-10-20 water soluble fertilizer (Fert., $20 \mathrm{~N}-4.4 \mathrm{P}-16.6 \mathrm{~K}-0.15 \mathrm{Mg}-0.02 \mathrm{~B}-0.01 \mathrm{Cu}-0.1 \mathrm{Fe}-0.05 \mathrm{Mn}-0.01 \mathrm{Mo}-$ $0.05 \mathrm{Zn}$ ). Substrate $\mathrm{pH}$ was recorded before irrigation (week 0 ) and at 4 and 8 weeks after initiating irrigation regime.

\begin{tabular}{|c|c|c|c|c|c|}
\hline Substrate & Acid/base & Fertilizer & $0 \mathrm{wk}$ & $4 \mathrm{wk}$ & $8 \mathrm{wk}$ \\
\hline \multirow[t]{6}{*}{$\overline{\text { Peatmoss }}$} & Water control & & 3.41 & 3.42 & 3.45 \\
\hline & $\mathrm{HCl}$ & & & 2.35 & 2.12 \\
\hline & $\mathrm{NaOH}$ & & & 3.47 & 3.71 \\
\hline & Water & Fert. & & 3.24 & 3.28 \\
\hline & $\mathrm{H}_{2} \mathrm{SO}_{4}$ & Fert. & & 2.90 & 2.28 \\
\hline & $\mathrm{KHCO}_{3}$ & Fert. & & 3.38 & 3.67 \\
\hline \multirow[t]{6}{*}{ Fine bark } & Water control & & 5.37 & 5.04 & 5.15 \\
\hline & $\mathrm{HCl}$ & & & 4.35 & 3.35 \\
\hline & $\mathrm{NaOH}$ & & & 6.01 & 6.67 \\
\hline & Water & Fert. & & 5.38 & 5.31 \\
\hline & $\mathrm{H}_{2} \mathrm{SO}_{4}$ & Fert. & & 4.96 & 3.93 \\
\hline & $\mathrm{KHCO}_{3}$ & Fert. & & 6.52 & 6.68 \\
\hline \multirow[t]{6}{*}{ Coarse bark } & Water control & & 4.81 & 4.82 & 4.87 \\
\hline & $\mathrm{HCl}$ & & & 3.65 & 2.58 \\
\hline & $\mathrm{NaOH}$ & & & 6.00 & 6.68 \\
\hline & Water & Fert. & & 5.04 & 4.73 \\
\hline & $\mathrm{H}_{2} \mathrm{SO}_{4}$ & Fert. & & 4.42 & 3.00 \\
\hline & $\mathrm{KHCO}_{3}$ & Fert. & & 6.73 & 6.90 \\
\hline $\operatorname{LSD}_{0.05^{z}}$ & & & 0.57 & 0.30 & 0.28 \\
\hline
\end{tabular}

${ }_{\mathrm{z}}$ Least significant difference among values within the same row.

irrigated with greenhouse tap water $( \pm 0.3$ units). The $\mathrm{pH}$ of sphagnum peat exposed to $\mathrm{HCl}$ decreased by 1.3 units from the initial measurement after 8 weeks. The $\mathrm{pH}$ of fine and coarse pine bark decreased 2.0 and 2.2 $\mathrm{pH}$ units, respectively, after 8 weeks. However, the change in molar $\mathrm{H}^{+}$concentration of sphagnum peat after 8 weeks was greater $\left(0.0072 \mathrm{M} \mathrm{H}^{+}\right)$than the change for the fine and medium pine bark (only 0.0004 and $0.0026 \mathrm{M}$ $\mathrm{H}^{+}$, respectively) due to the logarithmic nature of $\mathrm{pH}$ and the lower starting $\mathrm{pH}$ of the sphagnum peat substrate. Therefore, similar to the laboratory studies, sphagnum peat had a lower buffering capacity against acidic, low alkalinity solutions than pine bark. When irrigated with a basic, high-alkalinity solution using $\mathrm{NaOH}$, sphagnum peat $\mathrm{pH}$ increased by 1.3 units after 8 weeks, while fine and coarse bark increased 1.3 and 1.9 units, respectively. These data corroborate the results from our laboratory studies that pine bark is less buffered to changes in $\mathrm{pH}$ when irrigated with basic solutions.

Substrates were also irrigated with a standard greenhouse water-soluble fertilizer (acidic with a calcium carbonate equivalency of $200 \mathrm{~kg}$ per metric ton) and more traditional acidic and basic materials used during crop production $\left(\mathrm{H}_{2} \mathrm{SO}_{4}\right.$ and $\left.\mathrm{KHCO}_{3}\right)$. Similar to 
the water control treatment, the $\mathrm{pH}$ of substrates exposed to the water-soluble fertilizer were unaffected (Table 6). Although $\mathrm{pH}$ of the fertilizer solution was 1.5 units lower than the control water ( 7.27 vs. 8.72), both sources had similar alkalinity (Table 5). Irrigation water alkalinity has been shown to be more influential on substrate $\mathrm{pH}$ than irrigation water $\mathrm{pH}$ (Ramirez and Altland, 2018). Irrigating with fertilizer and $\mathrm{H}_{2} \mathrm{SO}_{4}$ decreased sphagnum peat $\mathrm{pH} 0.5$ and 1.1 units after 4 and 8 weeks, respectively. It decreased fine and coarse bark by 1.4 and $1.8 \mathrm{pH}$ units, respectively, after 8 weeks. Despite a greater decrease in $\mathrm{pH}$ in the two bark substrates compared with sphagnum peat, the change in molar $\mathrm{H}^{+}$concentration was less. Irrigating with fertilizer and $\mathrm{KHCO}_{3}$ increased $\mathrm{pH}$ of sphagnum peat $\mathrm{pH}$ by 0.3 units, fine bark by 1.3 units, and coarse bark by 2.1 units after 8 weeks. Similar to our laboratory experiments, sphagnum peat had a lower buffering capacity than pine bark against changes in acidity, whereas pine bark had a lower buffering capacity than sphagnum peat to changes in basicity.

There are several practical implications of this research. First, particle size appears to affect $\mathrm{pH}$ buffering of some organic substrates but not others, which may be due to their cation exchange capacity (CEC). CEC and $\mathrm{pH}$ buffering in organic matter are related, as both mechanisms are moderated by dissociation of carboxyl groups that act as sinks for $\mathrm{H}^{+}$and $\mathrm{OH}^{-}$(Curtin and Rostad, 1997; Parfitt et al., 1995). CEC in pine bark has been shown to increase with decreasing particle size over the range of 0.25 to $4 \mathrm{~mm}$ (Altland et al., 2014). The fine, medium, and coarse pine bark used in this study had different particle size distributions (Table 1). These three substrates, as well as bark screened to different particle sizes between 0.18 and $2.8 \mathrm{~mm}$, had demonstratable differences in $\mathrm{pH}$ buffering in basic solutions (Tables 3 and 4). In contrast, Altland et al. (2014) showed that CEC of sphagnum peat changed little with particle size over the range of 0.25 to $4 \mathrm{~mm}$, and likewise we had only minor differences in $\mathrm{pH}$ buffering in acidic and basic solutions using sphagnum peat particles screened to sizes ranging from 0.18 to $2.8 \mathrm{~mm}$ (Table 4).

Second, although not an objective of the experiment, the greenhouse study further illustrates how irrigation water alkalinity has a greater impact on substrate $\mathrm{pH}$ than irrigation water $\mathrm{pH}$. In a 17-week container study evaluating the effects of irrigation alkalinity from different water and fertilizer sources, Argo and Biernbaum (1996) also showed that substrate $\mathrm{pH}$ was similar when treated with irrigation water having similar alkalinity. Although irrigation water $\mathrm{pH}$ and alkalinity can be related, a survey of Ohio groundwater samples showed little correlation between the two variables $(R=-0.16726$,
$P=0.0006, R^{2}=0.027, \mathrm{n}=416$ ) (Anonymous, 2019). Therefore, knowing irrigation water $\mathrm{pH}$ alone is not adequate for understanding how substrate $\mathrm{pH}$ might change over time. Alkalinity is not easily measured by growers, but it is commonly included in most commercial and university water quality laboratory analyses.

Third, data from these experiments demonstrate that a singular value cannot be used to represent $\mathrm{pH}$ buffering of sphagnum peat and pine bark. Resistance to $\mathrm{pH}$ change of both substrates differed with exposure to acidic and basic solutions. In all cases, sphagnum peat was more susceptible to acidic changes but more resistant to basic changes compared with pine bark. The parameter $b$ of the log-logistic curve was suggested herein to be representative of buffering capacity because this parameter indicates the steepness of the change between the minimum and maximum horizontal asymptotes of the curve. However, based on our findings that individual substrate components and particle sizes can differ in their buffering capacity between acidic and basic solutions, a singular value such as parameter $b$ could be misleading.

Lastly, because sphagnum peat and pine bark are more buffered against changes in basic and acidic solutions, respectively, they might be used strategically in substrate blends to counter prevailing $\mathrm{pH}$ drivers. For example, growers might use a higher rate of sphagnum peat in substrates where high water alkalinity causes problems with $\mathrm{pH}$ increasing over time. In contrast, growers might use a higher rate of pine bark in situations where acidic fertilizers and low irrigation water alkalinity result in reduced substrate $\mathrm{pH}$ over time.

In summary, the objective of this research was to compare the $\mathrm{pH}$ buffering capacity of pine bark and its particle size fractions to sphagnum peat. We concluded that a singular value cannot accurately describe $\mathrm{pH}$ buffering against both acidic and basic drivers. Sphagnum peat used in this experiment was less buffered against acidic solutions than pine bark, but more buffered against basic solutions. The $\mathrm{pH}$ buffering of basic solutions in pine bark decreased with increasing particle size. Further research is needed to determine if the results of these particular batches of sphagnum peat and pine bark can be generalized across all sphagnum peats and barks.

\section{Literature Cited}

Albano, J.P., J. Altland, D.J. Merhaut, S.B. Wilson, and P. Wilson. 2017. Irrigation water acidification to neutralize alkalinity for nursery crop production: Substrate $\mathrm{pH}$, electrical conductivity, nutrient concentrations, and plant nutrition and growth. HortScience 52:1401-1405.

Altland, J.E. and K.Y. Jeong. 2016. Dolomitic lime amendment affects pine bark substrate $\mathrm{pH}$, nutrient availability, and plant growth: A review. HortTechnology 26:565-573.
Altland, J.E., J.C. Locke, and C.R. Krause. 2014. Influence of pine bark particle size and $\mathrm{pH}$ on cation exchange capacity. HortTechnology 24:554-559.

Altland, J.E., J. Owen, B. Jackson, and J. Fields. 2018. Physical and hydraulic properties of commercial pine-bark substrate products used in production of containerized crops. HortScience 53:1883-1890.

Anonymous. 2019. Ohio Environmental Protection Agency ground water quality characterization program. 17 Oct. 2019. <https://epa.ohio.gov/ ddagw/gwqcp>.

Argo, W.R. and J.A. Biernbaum. 1996. The effect of lime, irrigation-water source, and watersoluble fertilizer on root-zone $\mathrm{pH}$, electrical conductivity, and macronutrient management of container root media with impatiens. J. Amer. Soc. Hort. Sci. 121:442-452.

Argo, W.R. and P.R. Fisher. 2002. Understanding $\mathrm{pH}$ management for container-grown crops. Meister Pub. Co., Willoughby, OH.

Curtin, D. and H.P.W. Rostad. 1997. Cation exchange and buffer potential of Saskatchewan soils estimated from texture, organic matter and pH. Can. J. Soil Sci. 77:621-626.

Elliott, G.C. 1996. pH management in container media. Commun. Soil Sci. Plant Anal. 27:635649.

Fonteno, W.C. and T.E. Bilderback. 1993. Impact of hydrogel on physical properties of coarsestructured horticultural substrates. J. Amer. Soc. Hort. Sci. 118:217-222.

Harvey, M.P., G.C. Elliott, and M.H. Brand. 2004 Growth response of Hakonechloa macra (Makino) 'Aureola' to fertilizer formulation and concentration, and to dolomitic lime in the potting mix. HortScience 39:261-266.

Jackson, B.E., R.D. Wright, and M.C. Barnes. 2010. Methods of constructing a pine tree substrate from various wood particle sizes, organic amendments, and sand for desired physical properties and plant growth. HortScience 45:103-112.

Johnson, C.N., P.R. Fisher, J. Huang, T.H. Yeager, T.A. Obreza, R.P. Vetanovetz, W.R. Argo, and A.J. Bishko. 2013. Effect of fertilizer potential acidity and nitrogen form on the $\mathrm{pH}$ response in a peat-based substrate with three floricultural species. Scientia Hort. 162:135-143.

Lang, H.J. and G.C. Elliott. 1991. Influence of ammonium: Nitrate ratio and nitrogen concentration on nitrification activity in soilless potting media. J. Amer. Soc. Hort. Sci. 116: 642-645.

Parfitt, R.L., D.J. Giltrap, and J.S. Whitton. 1995. Contribution of organic matter and clay minerals to the cation exchange capacity of soils. Commun. Soil Sci. Plant Anal. 26:1343-1355.

Ramirez, S.V. and J.E. Altland. 2018. Minding your pHs and Qs. GrowerTalks 81(11):68-69.

Rippy, J.F.M., P.V. Nelson, D.L. Hesterberg, and E.J. Kamprath. 2007. Reaction times of twenty limestones. Commun. Soil Sci. Plant Anal. 38:1775-1783.

Taylor, M.D., P.V. Nelson, and J.M. Frantz. 2008 Substrate acidification by geranium: Light effects and phosphorus uptake. J. Amer. Soc. Hort. Sci. 133:515-520.

Walden, R.F. and G. Epelman. 1988. Influence of liming rate on growth of Japanese boxwood in pine bark media. Proc. Southern Nursery Assn. Res. Conf. 33:52-57. 